\title{
PENGARUH ADAPTABILITAS BUDAYA ORGANISASI DAN MOTIVASI TERHADAP KOMITMEN KARYAWAN PADA ORGANISASI PT KRAKATAU STEEL TBK
}

\author{
Tassya Wulandary")1, Muhammad Syamsun*), dan Sukiswo Dirjosuparto*) \\ **) Departemen Manajemen, Fakultas Ekonomi Dan Manajemen, Institut Pertanian Bogor \\ Jl. Kamper, Wing 2 Level 5 Kampus IPB Darmaga, Bogor 16680
}

\begin{abstract}
This study aimed to analyze the influence of the adaptability of organizational culture on employee commitment to the organization of PT Krakatau Steel Tbk and analyze the influence of motivation on employee commitment to the company. The 161 respondents in this study were obtained by the census research method, and they are full-time employees who are placed at the financial directorate. This research methods used were descriptive analysis and structural equation modeling equation modeling (SEM) by the method of partial least square (PLS). Latent variables in this study are the adaptability of the organizational culture, motivation and organizational commitment. Based on the results of the study, overall, the variables of adaptability organizational culture and motivation (hygiene factors) are influential toward the commitment of the employees of PT Krakatau Steel Tbk.
\end{abstract}

Keywords: organizational culture adaptability, hygiene, motivator, organizational commitment, structural equation modeling (SEM)

\begin{abstract}
ABSTRAK
Penelitian ini bertujuan untuk menganalisis pengaruh adaptabilitas budaya organisasi terhadap komitmen karyawan pada organisasi PT Krakatau Steel Tbk serta menganalisis pengaruh motivasi terhadap komitmen karyawan pada organisasi PT Krakatau Steel Tbk. Responden dalam penelitian ini sebanyak 161 orang dengan metode penelitian sensus terhadap karyawan tetap yang memiliki penempatan di direktorat keuangan. Metode penelitian ini menggunakan analisis deskriptif dan pemodelan persamaan struktural equation model (SEM) dengan metode parsial least square (PLS). Variabel laten pada penelitian ini adalah adaptabilitas budaya organisasi, motivasi \& komitmen organisasi. Berdasarkan hasil penelitian, secara keseluruhan memengaruhi komitmen karyawan di PT Krakatau Steel Tbk yaitu variabel adaptabilitas budaya organisasi dan motivasi (faktor hygiene).
\end{abstract}

Kata kunci : adaptabilitas budaya organisasi, hygiene, motivator, komitmen organisasi, struktural equation model (SEM)

${ }^{1}$ Alamat Korespondensi:

Email: wulandary.tassya@yahoo.co.id

\section{PENDAHULUAN}

Sumber daya manusia (SDM) merupakan faktor penting dalam suatu organisasi. Melimpahnya SDM yang ada saat ini mengharuskan suatu organisasi untuk berpikir secara seksama tentang bagaimana dapat memanfaatkan SDM secara optimal. Sumber daya manusia yang ada pada perusahaan harus selalu diberdayakan agar menjadi SDM yang kompetitif. Banyak organisasi yang menghadapi tantangan ini dengan membangun komitmen dengan para karyawan dalam upaya meningkatkan kualitas. Jika SDM dikelola secara tepat maka organisasi akan bergerak secara dinamis dan berkembang dengan pesat (Abrivianto, 2014).

Bagi kehidupan organisasi, komitmen merupakan prasyarat untuk menjaga kelangsungan hidup organisasi. Yilmaz (2008) mengemukakan bahwa komitmen organisasi adalah tingkat dimana karyawan mengkaitkan dirinya ke organisasi tertentu dan sasaransasarannya dan berharap mempertahankan keanggotaan dalam organisasi tersebut. Komitmen yang dibutuhkan 
adalah komitmen dari seluruh anggota organisasi untuk kepentingan organisasinya. Komitmen organisasi yang tinggi pada karyawan akan cenderung membuat karyawan berdedikasi tinggi dalam bekerja. Karyawan yang memiliki komitmen yang tinggi pada organisasi cenderung lebih stabil, setia, bekerja sebaik dan seproduktif mungkin sehingga lebih menguntungkan organisasi. Rashid et al. (2003) menyatakan bahwa komitmen organisasi merupakan suatu kondisi psikologis yang menandai hubungan antara karyawan dengan organisasinya. Adanya komitmen organisasi sangat menguntungkan untuk kepentingan organisasi dan karyawan dalam mewujudkan program organisasi.

Keberadaan komitmen organisasi dalam diri karyawan bukan hanya berasal dari individu yang bersangkutan tetapi dapat dipengaruhi oleh faktor - faktor lain yang berhubungan dengan individu tersebut. Faktor - faktor yang dapat memengaruhi komitmen organisasi adalah adaptabilitas budaya organisasi dan motivasi. Pesatnya laju perubahan lingkungan seperti saat ini menyadarkan organisasi akan semakin pentingnya adaptabilitas, yakni kemampuan untuk tanggap akan lingkungan eksternal, pelanggan internal, dan pelanggan eksternal dengan cara menerjemahkan permintaan lingkungan bisnis menjadi tindakan agar perusahaan bertahan, bertumbuh, dan berkembang (Denison dan Aniel, 1990). Adaptabilitas budaya organisasi adalah tingkat keefektifan budaya organisasi dalam menghadapi tantangan - tantangan yang ada dan merespon perubahan - perubahan yang akan dilakukan. Budaya organisasi harus bersifat dinamis dan adaptif terhadap lingkungan organisasi jika menginginkan kinerja yang baik untuk jangka panjang. Oleh karena itu, budaya adaptif adalah salah satu faktor penting agar organisasi tetap bertahan.

Kotter dan Heskett (1998) mengemukakan bahwa budaya organisasi merupakan seperangkat nilai, norma, persepsi dan perilaku yang diciptakan dan dikembangkan suatu organisasi untuk mengatasi masalah-masalah, baik masalah mengenai integrasi internal maupun masalah mengenai adaptasi eksternal. Budaya organisasi berfungsi sebagai alat untuk mencapai tujuan perusahaan dan sebagai tuntunan bagi para karyawan dalam berperilaku dan bertindak atau berisikan larangan untuk melakukan suatu tindakan dalam menghadapi suatu tantangan lingkungan. Hal ini berarti budaya organisasi yang tumbuh dan terpelihara dengan baik akan mampu memacu organisasi ke arah perkembangan yang lebih baik. Selain itu, tekanan utama dalam perubahan dan pengembangan budaya organisasi adalah mencoba untuk mengubah nilainilai, sikap dan perilaku dari anggota organisasi secara keseluruhan.

Motivasi adalah kemauan untuk memberikan upaya lebih untuk meraih tujuan organisasi yang disebabkan oleh kemauan untuk memuaskan kebutuhan individual (Robbins, 1996). Motivasi kerja mempunyai peranan yang penting dalam hal tumbuhnya semangat untuk bekerja secara optimal dan merasa senang. Karyawan yang memiliki motivasi kerja yang kuat akan mempunyai banyak energi untuk melakukan kegiatan. Hasil kerja akan optimal apabila ada motivasi yang tepat. Dengan adanya motivasi yang tepat para karyawan akan terdorong untuk berbuat semaksimal mungkin dalam melaksanakan tugasnya karena meyakini bahwa dengan keberhasilan organisasi dalam mencapai tujuan dan berbagai sasarannya, kepentingan - kepentingan pribadi para anggota organisasi tersebut akan tercapai pula. Dengan motivasi yang tinggi akan menciptakan sebuah komitmen terhadap apa yang menjadi tanggung jawabnya dalam menyelesaikan setiap pekerjaan (McNeese-Smith et al.1996).

PT Krakatau Steel Tbk merupakan salah satu perusahaan baja terbesar di Indonesia yang berlokasi di Cilegon, Banten. Perusahaan ini bergerak di bidang produksi dan penjualan besi dan baja yang didirikan pada tahun 1970. Perusahaan memiliki kapasitas produksi baja kasar sebesar 2,45 juta ton per tahun. Kapasitas ini digunakan untuk mendukung produksi komoditi perusahaan yaitu berupa baja lembaran panas, baja lembaran dingin, batang kawat, pipa spiral, pipa ERW, baja tulangan dan baja profil. Selain memasarkan produknya secara nasional, PT Krakatau Steel Tbk memasarkan produknya secara internasional. Oleh karena itu, dengan keahliannya dalam memproduksi baja, perusahaan menguatkan posisinya sebagai salah satu industri strategis di Indonesia (Data Internal PT Krakatau Steel, 2016).

Berdirinya PT Krakatau Steel Tbk telah menempatkan karyawan sebagai aset terpenting perusahaan. Karyawan PT Krakatau Steel Tbk berada dalam tatanan struktur birokrasi. Perubahan lingkungan birokrasi yang fleksibel merupakan dinamika yang telah menciptakan tantangan yang harus dihadapi oleh organisasi. Beberapa faktor yang dapat memengaruhi antara lain, adaptabilitas budaya organisasi, motivasi dan komitmen. 
Dalam upaya mencapai kemajuan organisasi, PT Krakatau Steel Tbk dihadapkan pada beberapa permasalahan yang terkait dengan perilaku karyawan dalam upaya peningkatan kinerja karyawan maupun organisasi. Semangat kerja karyawan yang rendah tercermin dari perilaku karyawan yang tidak menaati peraturan yang telah ditetapkan. Adanya permasalahan tersebut berdampak terhadap pekerjaan yang tidak dapat diselesaikan sesuai dengan harapan dan waktu yang ditentukan. Maka penelitian ini menjadi sangat penting untuk melihat komitmen organisasi melalui perspektif adaptabilitas budaya organisasi dan motivasi.

Permasalahan yang ada di PT Krakatau Steel Tbk akan dikaji berdasarkan aspek adaptabilitas budaya organisasi dan motivasi yang akan dilihat pengaruhnya terhadap komitmen organisasi. Berdasarkan penelitian yang dikaji, maka tujuan penelitian yang ingin dicapai adalah menganalisis pengaruh adaptabilitas budaya organisasi terhadap komitmen organisasi PT Krakatau Steel Tbk serta menganalisis pengaruh motivasi terhadap komitmen organisasi PT Krakatau Steel Tbk.

\section{METODE PENELITIAN}

Jenis data yang digunakan dalam penelitian ini adalah data primer yaitu data yang bersumber dari hasil penelitian lapangan berupa penyebaran kuesioner yang berisi sejumlah pertanyaan tertulis yang digunakan untuk memperoleh informasi dari responden di Direktorat Keuangan PT Krakatau Steel Tbk. Selain data primer, peneliti juga menggunakan data sekunder, yaitu data yang berasal dari sumber lainnya. Data sekunder diperoleh dari Direktorat Keuangan PT Krakatau Steel Tbk, serta literatur yang berkaitan dengan penelitian seperti buku, jurnal dan pustaka lainnya yang bersumber dari internet.

Responden dalam penelitian ini adalah karyawan tetap yang memiliki penempatan di Direktorat Keuangan PT Krakatau Steel Tbk yang berlokasi di Cilegon, Banten. Penelitian ini dibatasi oleh ruang lingkup pada analisis pengaruh adaptabilitas budaya organisasi dan motivasi terhadap komitmen karyawan pada organisasi PT Krakatau Steel Tbk. Variabel motivasi pada penelitian ini menggunakan teori Herzberg. Penelitian ini menggunakan data primer yang diperoleh dari data hasil kuesioner dan wawancara karyawan PT Krakatau Steel Tbk serta informasi yang berkaitan dengan sumber daya manusia.
Penelitian ini menggunakan metode penelitian sensus terhadap karyawan tetap yang memiliki penempatan di Direktorat Keuangan PT Krakatau Steel Tbk yang berjumlah 161 orang sehingga populasi tersebut menjadi anggota yang diamati sebagai ciri populasi (parameter) secara akurat dan komprehensif. Jumlah karyawan tetap PT Krakatau Steel Tbk dapat dilihat pada Tabel 1.

Tabel 1. Jumlah karyawan tetap PT Krakatau Steel Tbk

\begin{tabular}{lc}
\hline \multicolumn{1}{c}{ Penempatan } & $\begin{array}{c}\text { Jumlah } \\
\text { karyawan tetap }\end{array}$ \\
\hline Direktorat Utama & 77 \\
Direktorat Logistik & 126 \\
Direktorat Produksi \& Teknologi & 3.133 \\
Direktorat Pemasaran & 194 \\
Direktorat Keuangan & 161 \\
Direktorat SDM \& Pengembangan & 878 \\
Usaha & \\
\hline \multicolumn{1}{c}{ Jumlah } & 4.569 \\
\hline
\end{tabular}

Analisis data yang dilakukan dalam penelitian ini adalah menggunakan metode Structural Equation Modelling (SEM) dengan pendekatan Partial Least Square (PLS) di mana perhitungan statistiknya dilakukan dengan software SmartPLS versi 3.0. Analisis data dengan Partial Least Square (PLS) tidak mengasumsikan adanya distribusi tertentu untuk estimasi parameter, sehingga teknik parametik untuk menguji signifikansi parameter tidak diperlukan (Chin, 1998 dalam Ghazali, 2008). Variabel dalam penelitian ini terdiri dari tiga variabel, yaitu adaptabilitas budaya organisasi (X1), motivasi (X2) dan komitmen organisasi (Y). Setiap variabel laten memiliki masing-masing variabel manifest (indikator) sesuai yang telah dijabarkan sebelumnya pada operasionalisasi variabel.

Kerangka pemikiran penelitian ini diawali dengan uji pengaruh adaptabilitas budaya organisasi dan motivasi terhadap komitmen organisasi. Informasi yang didapatkan untuk melakukan uji pengaruh adaptabilitas budaya organisasi dan motivasi terhadap komitmen organisasi didapatkan dari wawancara dan kuesioner. Di dalam mencari pengaruh adaptabilitas budaya organisasi dan motivasi terhadap komitmen organisasi, penelitian ini menggunakan alat analisis SEM dengan variabel laten eksogen yaitu adaptabilitas budaya organisasi dan motivasi dan variabel laten endogen yaitu komitmen organisasi. Hasil dari pengaruh adaptabilitas budaya organisasi dan motivasi terhadap komitmen 
organisasi akan mengarahkan manajemen dalam melakukan implikasi manajerial untuk melakukan tindakan-tindakan yang dapat mencapai komitmen yang optimal karyawannya. Dengan adanya upaya tersebut maka diharapkan komitmen karyawan akan meningkat. Alur pemikiran dari penelitian ini dapat dilihat pada Gambar 1.

Hipotesis yang diajukan untuk penelitian ini, yaitu sebagai berikut :

1. Hipotesis Model 1: Model Pengaruh Langsung (Direct effect)

$\mathrm{H} 1$ = Adaptabilitas budaya organisasi berpengaruh signifikan terhadap komitmen karyawan pada organisasi PT Krakatau Steel Tbk

$\mathrm{H} 2$ = Motivasi berpengaruh signifikan terhadap komitmen karyawan pada organisasi PT Krakatau Steel Tbk

2. Hipotesis Model 2: Model Pengaruh Tidak Langsung (Indirect effect)

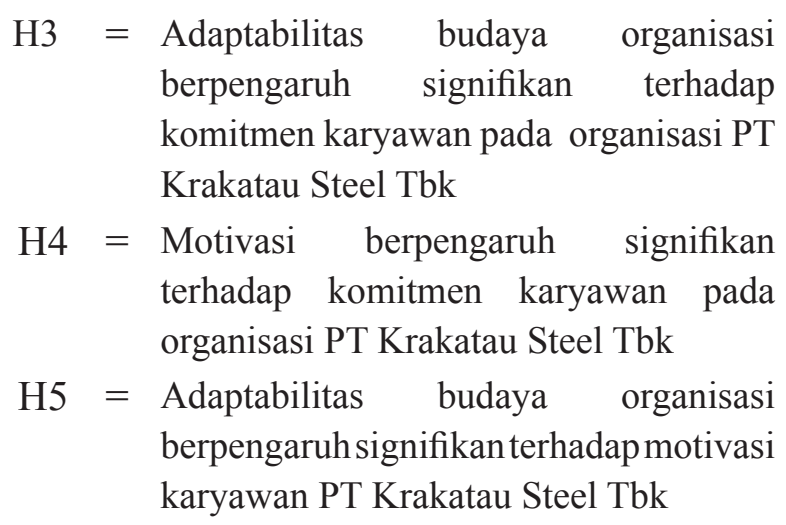

\section{HASIL}

Jumlah karyawan di Direktorat Keuangan PT Krakatau Steel Tbk sebanyak 161 orang yang terdiri dari lakilaki dan perempuan karyawan yang berjenis kelamin pria sebanyak 135 orang atau $84 \%$ dan wanita sebanyak 26 orang atau $16 \%$. Pada dasarnya perbedaan antara keduanya terlalu signifikan sehingga memberikan gambaran kepada kita bahwa PT Krakatau Steel Tbk membeda-bedakan gender dalam merekrut dan mempekerjakan karyawan. Selain itu, jenis pekerjaan yang lebih cenderung ke hal-hal administrasi dan membutuhkan kerapihan serta ketekunan, yang biasanya dilakukan oleh wanita, tidak menjadikan PT Krakatau Steel Tbk langsung memilih karyawan wanita untuk mengisi pos-pos pekerjaan tersebut. Semuanya dikembalikan pada kemampuan dan kompetensi masing-masing karyawan. Usia karyawan di Direktorat Keuangan PT Krakatau Steel Tbk berkisar antara usia 20 tahun sampai dengan lebih dari 50 tahun yang memiliki taraf pendidikan SMA yaitu sebanyak 45 orang atau $28 \%$. Pada kenyataannya terdapat karyawan dengan tingkat pendidikan D3 sebanyak 36 orang atau $22 \%$ dan S1 sebanyak 80 orang atau $50 \%$. Hal ini terjadi karena para responden merupakan karyawan yang memiliki masa kerja yang cukup lama (lebih dari 10 tahun) yang memulai karirnya dari jabatan paling rendah, sehingga posisi mereka saat ini lebih dipengaruhi oleh jasa dan prestasi mereka terhadap organisasi. Berbanding lurus dengan usia, responden di dominasi oleh karyawan dengan masa kerja 11-15 tahun yaitu sebanyak 56 orang. Berdasarkan status karyawan, jumlah karyawan $100 \%$ merupakan karyawan staf financial accounting.

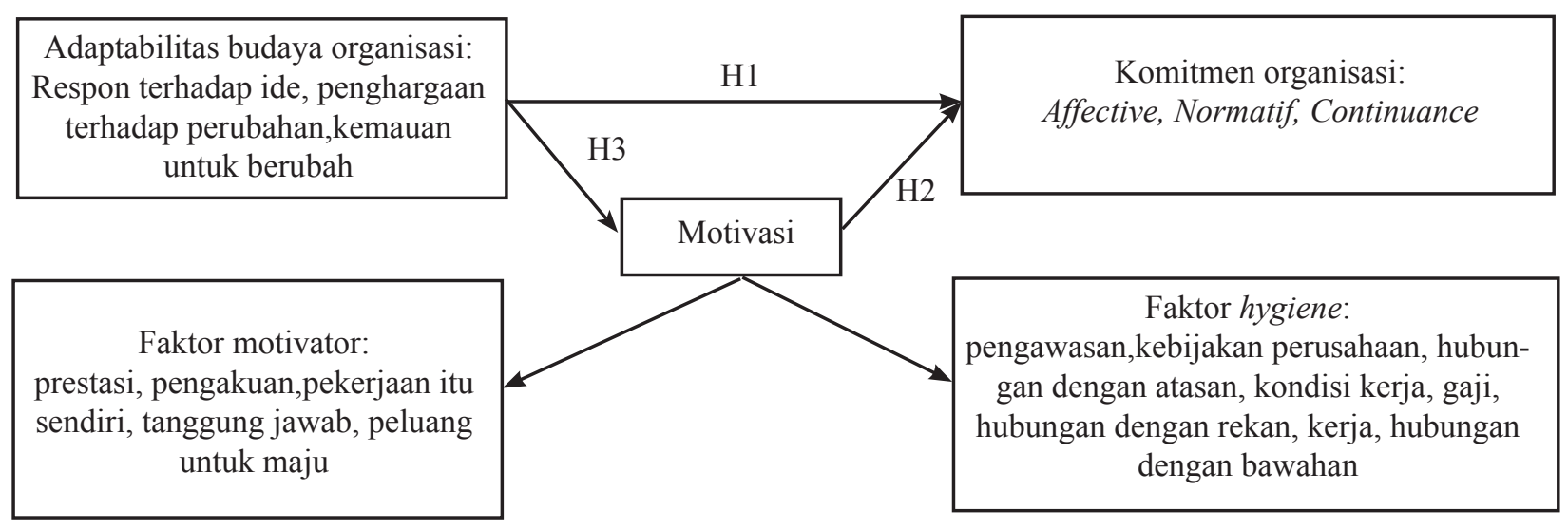

Gambar 1. Alur pemikiran dari penelitian 


\section{Adaptabilitas Budaya Organisasi dan Motivasi terhadap Komitmen Organisasi Karyawan pada PT Krakatau Steel Tbk}

Analisis SEM PLS yang dilakukan pada penelitian ini menggunakan dua model analisis yaitu outer model dan inner model. Metode analisis yang dilakukan untuk mengetahui bentuk dan besar pengaruh variabel laten independen (eksogen) yaitu adaptabilitas budaya organisasi dan motivasi terhadap variabel laten dependen (endogen) yaitu komitmen organisasi. Analisis data yang dilakukan dengan menggunakan metode SEM dengan pendekatan PLS. Dalam penelitian ini software yang digunakan adalah SmartPLS versi 3.0 untuk mengetahui pengaruh peubah laten bebas dengan peubah laten tidak bebas. Tujuan menggunakan metode analisis ini untuk melihat besarnya pengaruh variabel adaptabilitas budaya organisasi dan variabel motivasi terhadap variabel komitmen organisasi. Terdapat tiga variabel laten yang digunakan dalam penelitian ini yaitu, adaptabilitas budaya organisasi, motivasi dan komitmen organisasi. Setiap variabel laten masingmasing memiliki indikator yang telah dijelaskan sebelumnya.

Penelitian ini menggunakan indikator berbentuk reflektif pada peubah latennya. Indikator-indikator pada model reflektif yang memiliki nilai kecil pada model awal dianggap tidak mempunyai pengaruh kuat terhadap laten tersebut sehingga indikator tersebut dihilangkan atau di hapus. Ukuran refleksi indikator dengan konstruknya dikatakan tinggi jika memiliki nilai loading factor $\geq 0,7$. Akan tetapi, untuk pengembangan pada tahap awal, nilai loading factor 0,5-0,6 dianggap cukup. Pada penelitian ini indikator yang memiliki nilai loading factor di bawah 0,7 akan dieliminasi atau dihapus. Tahapan eliminasi dilakukan dengan satu persatu di mulai dari nilai loading factor yang terkecil. Proses eliminasi tersebut dilakukan berulang-ulang sampai seluruh indikator memiliki nilai loading factor minimal 0,7 untuk memperoleh model terbaik. Setelah melakukan proses eliminasi terhadap indicator yang tidak berpengaruh maka didapat outer model akhir. Outer model akhir menggambarkan bahwa komitmen masing-masing memiliki beberapa indicator yang mempunyai nilai loading factor yang $\geq 0,7$. Artinya, indikator tersebut terbukti mempunyai pengaruh terhadap variabel laten dari indikator tersebut.

\section{Evaluasi Outer Model}

Analisis outer model penelitian yang dapat dilihat pada Gambar 2 adalah variabel adaptabilitas budaya organisasi memiliki 10 indikator reflektif, yaitu respon terhadap ide (pimpinan saya menghargai ide-ide yang baik untuk memajukan dan mengembangkan organisasi (X1.1)), (pimpinan saya mengakomodir ide-ide dan saran dari para karyawan (X1.2)), (ide-ide yang baik tidak selalu direspon ke tingkat atas karena pimpinan tidak dekat dengan karyawan (X1.3)), penghargaan terhadap perubahan (pimpinan mengambil keputusan atas dasar rekomendasi dari orang-orang di unit saya (X1.4)), (organisasi memberikan penghargaan pada saya apabila mengatasi masalah (X1.5)), (karyawan mempunyai kebebasan untuk merekomendasikan kepada pimpinan untuk merubah praktek-praktek yang berjalan (X1.6)), kemauan untuk berubah (ketika saran ditujukan untuk pimpinan, mereka menerimanya secara bijak (X1.7)), (organisasi tidak mengharapkan saya untuk menentang (X1.8)), (organisasi secara khusus mendorong saya membawa perbaikan di tempat kerja (X1.9)), (organisasi mengharapkan saya untuk meningkatkan prosedur unit kerja dan praktekpraktek yang berjalan (X1.10)). Hal ini sesuai dengan penelitian Trang (2013), yang menyatakan secara simultan gaya kepemimpinan dan budaya organisasi berpengaruh nyata dan positif terhadap kinerja. Secara parsial, gaya kepemimpinan berpengaruh, tetapi tidak nyata. Budaya organisasi berpengaruh nyata dan positif terhadap kinerja.

Nilai loading factor yang dimiliki masing-masing indikator variabel adaptabilitas budaya organisasi dapat dibilang cukup tinggi, dengan nilai loading factor yang paling tinggi dimiliki oleh (X1.8, organisasi tidak mengharapkan saya untuk menentang dengan nilai loading factor sebesar 0,614). Hasil penilaian mode reflektif pada outer model dapat dilihat pada Tabel 2 .

Indikator yang digunakan dalam penelitian ini berbentuk reflektif dan analisis outer model yang digunakan juga pada mode reflektif. Pengujian model reflektif terlebih dahulu dilakukan dengan beberapa kriteria, yaitu convergent validity, composite reliability, Average variance extracted (Ghozali, 2008). Convergent validity merupakan besarnya loading factor untuk masing-masing konstruk. Dalam penelitian ini semua indikator memiliki nilai di atas 0,5. Composite reliability menunjukkan konsistensi internal dengan standar nilai di atas 0,7 . Average variance extracted 
(AVE) menunjukkan validitas konstruk dengan standar nilai lebih besar dari 0,5. Hasil analisis outer model pada mode reflektif dapat di lihat pada Gambar 2.

Nilai loading factor yang dimiliki masing-masing indikator variabel motivasi dapat dibilang cukup tinggi, di mana nilai loading factor untuk bagian hygiene dimiliki oleh (X2.17, gaji yang saya terima sesuai dengan kemampuan kerja saya) dengan nilai loading factor sebesar 0,664. Di pihak lain, nilai loading factor yang memperoleh nilai cukup tinggi untuk bagian motivator adalah (X2.29, organisasi memberikan perhatian dan penghargaan bagi karyawan yang memiliki kejujuran dan semangat tinggi) dengan nilai loading factor sebesar 0,551 .

Pada Gambar 2, variabel komitmen direfleksikan oleh 10 indikator, yaitu affective commitment (saya sangat senang menghabiskankarir saya diorganisasiini(Y1.1)), (saya merasa menjadi bagian keluarga di organisasi ini (Y1.2)), (saya bangga dapat bekerja di organisasi ini (Y1.3)), normative commitment (saya merasa bahwa loyalitas yang saya berikan untuk organisasi ini adalah sebuah kewajiban untuk saya (Y1.4)), (meninggalkan organisasi ini bukanlah merupakan sebuah pilihan (Y1.5)), (saya merasa bahwa masalah organisasi adalah masalah saya juga (Y1.6)), (saya merasa berhutang budi kepada organisasi (Y1.7)), continuance commitment (saya akan mengalami kerugian apabila keluar dari organisasin ini (Y1.8)), (merupakan suatu kewajaran bagi saya untuk menetap di organisasi ini (Y1.9)), (saya merasa enggan berhenti bekerja dari organisasi ini karena ketidakpastian pekerjaan di tempat lain (Y1.10)). Nilai loading factor yang dimiliki masing-masing indikator variabel komitmen dapat di bilang cukup tinggi, di mana nilai loading factor yang paling tinggi dimiliki oleh (Y1.1, saya sangat senang menghabiskan karir saya di organisasi ini) dengan nilai loading factor sebesar 0,805 .
Penelitian Sumarno (2005) mengatakan pengaruh komitmen organisasi terhadap kinerja lebih besar dibanding gaya kepemimpinan terhadap kinerja. Pencapaian target yang mengandalkan gaya kepemimpinan dan motivasi tanpa bentuk komitmen nyata seperti menaati jam masuk kerja dan memenuhi persyaratan proses yang sudah disepakati tidak meningkatkan kinerja secara nyata. Pembentukan komitmen organisasi merupakan hasil dari input gaya kepemimpinan dan motivasi. Proses yang menentukan kinerja akan cepat meningkat atau tidak ada di faktor komitmen organisasi. Pengaruh gaya kepemimpinan terhadap motivasi kerja, lebih besar dibanding pengaruh motivasi kerja terhadap gaya kepemimpinan. Hal ini berarti, faktor gaya kepemimpinan menentukan peningkatan motivasi kerja. Penelitian ini dapat dijadikan salah satu acuan untuk membuat strategi organisasi untuk meningkatkan komitmen pada karyawan PT Krakatau Steel Tbk.

\section{Model Struktural (Inner Model)}

Pada penelitian ini $\mathrm{R}^{2}$ dari peubah laten endogen adalah komitmen, hygiene, dan motivator. Nilai dari $\mathrm{R}^{2}$ tersebut dapat diinterpretasikan bahwa hygiene dan motivator dibentuk oleh peubah eksogen adaptabilitas budaya organisasi dengan nilai $\mathrm{R}^{2}$ sebesar 0,266 dan 0,191 artinya bahwa peubah hygiene dan motivator dapat dijelaskan oleh peubah adaptabilitas budaya organisasi sebesar 26,6\% dan 19,1\%. Peubah komitmen dibentuk oleh peubah hygiene, motivator dan peubah adaptabilitas budaya organisasi memiliki $\mathrm{R}^{2}$ sebesar 0,383 artinya peubah komitmen dapat dijelaskan oleh peubah hygiene, motivator dan peubah adaptabilitas budaya organisasi sebesar 38,3\%. Menurut Ghozali (2008), nilai $\mathrm{R}^{2}$ dikelompokkan sebesar 0,67, 0,33, 0,19 sebagai substansial, moderate, dan lemah. Dapat dikatakan nilai $\mathrm{R}^{2}$ yang dihasilkan dikategorikan (di antara moderate dan lemah). Inner model dapat di lihat pada Gambar 3.

Tabel 2. Hasil penilaian mode reflektif pada outer model

\begin{tabular}{lcl}
\hline \multicolumn{1}{c}{ Kriteria } & Standar & \multicolumn{1}{c}{ Hasil penilaian } \\
\hline Composite reliability & $\geq 0,7$ & Adaptabilitas Budaya Organisasi $=0,525$ \\
Cronbach's alpha & $\geq 0,7$ & Adaptabilitas Budaya Organisasi $=0,358$ \\
Loading factor & $\geq 0,5$ & $\begin{array}{l}\text { Masing-masing indikator memiliki nilai loading factor } \geq 0,5 . \\
\text { Indikator yang memiliki nilai loading factor } \leq 0,5 \text { dilakukan } \\
\text { Average Covariance Extracted (AVE) }\end{array}$ \\
& & $\begin{array}{l}\text { eliminasi pada indikator tersebut. } \\
\text { Masing-masing laten memiliki nilai AVE } \leq 0,5 \text { maka dapat } \\
\text { dikatakan model yang digunakan tidak valid. }\end{array}$ \\
\hline
\end{tabular}




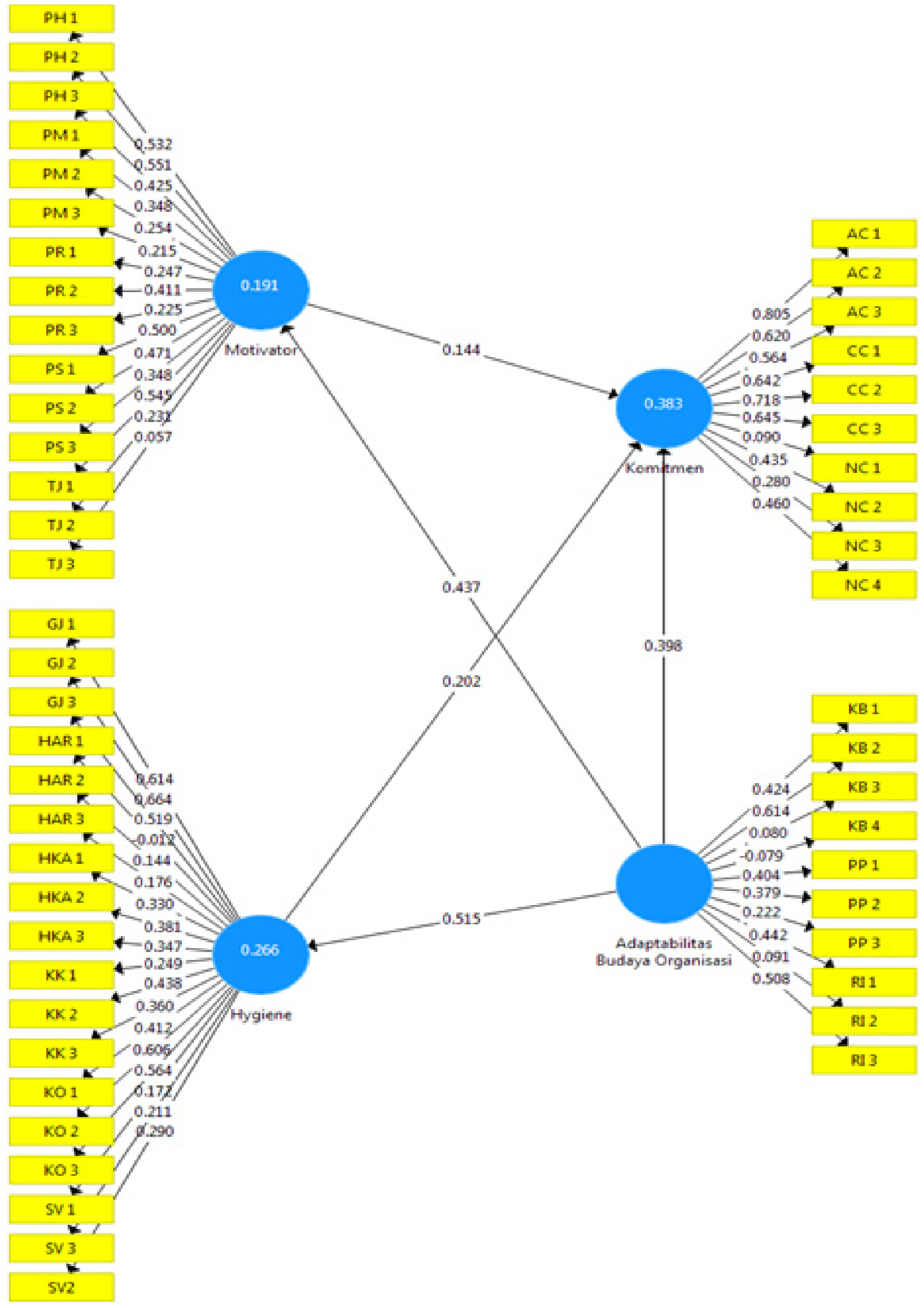

Gambar 2. Model akhir pengaruh langsung (direct effect) dan tidak langsung (indirect effect) 


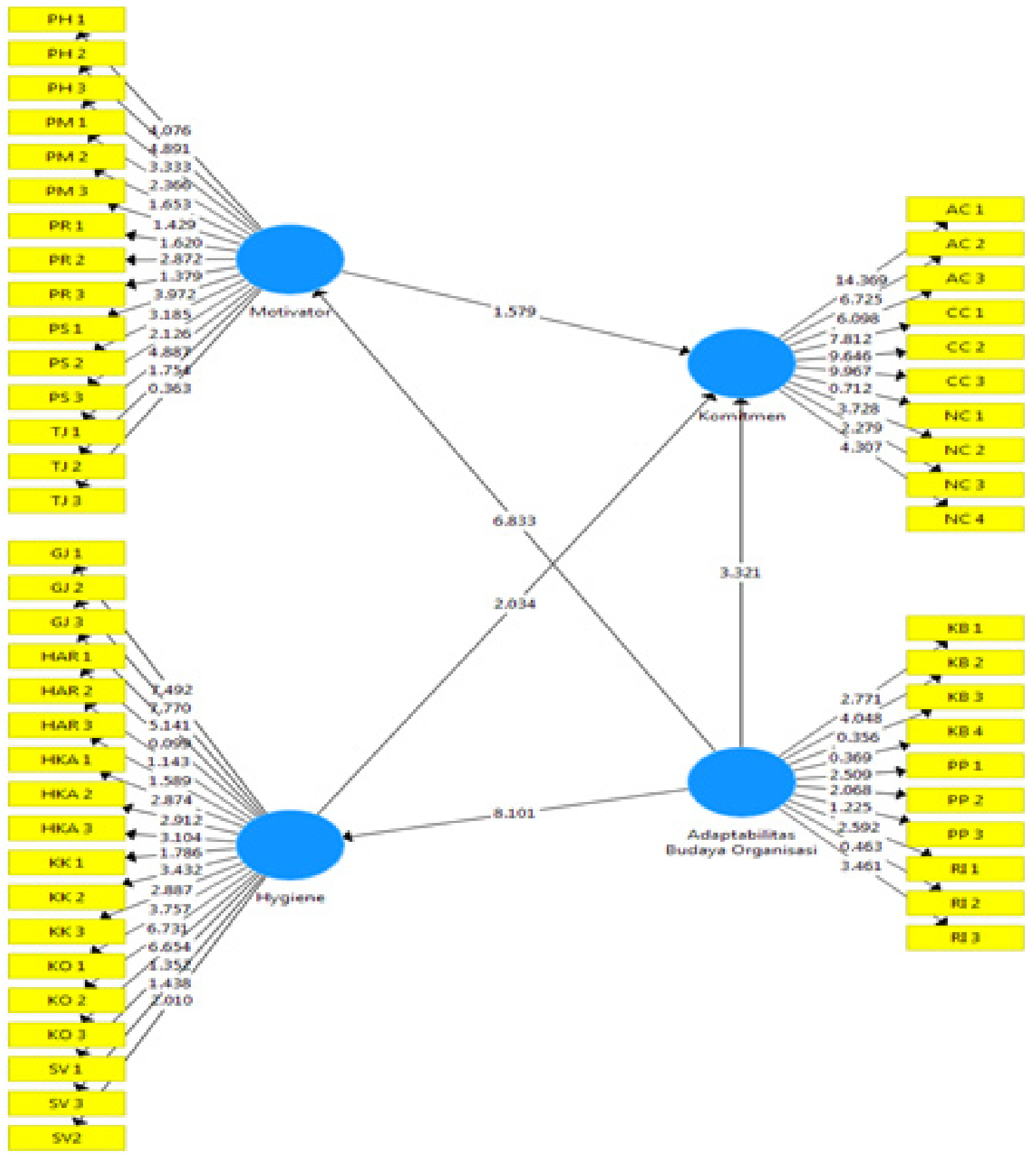

Gambar 3. Hasil metode bootsrapping model pengaruh langsung (direct effect) dan tidak langsung (indirect effect).

Estimasi koefisien path adalah evaluasi terhadap nilai koefisien, pengaruh nyata dari nilai bootstrapping dan besarnya nilai koefisien. Pengujian hipotesis dilakukan dengan membandingkan $\mathrm{T}$ hitung dengan $\mathrm{T}$ tabel. Jika nilai Thitung $>\mathrm{T}$ tabel $(1,96)$ maka perumusan hipotesis diterima namun jika nilai $\mathrm{T}$ hitung $<\mathrm{T}$ tabel (1.96) maka perumusan hipotesis ditolak. Nilai koefisien path dapat di lihat pada Tabel 2. Hasil koefisien path menggambarkan adaptabilitas budaya organisasi secara langsung berpengaruh positif dan signifikan terhadap komitmen pada taraf nyata 0,05 . Variabel adaptabilitas budaya organisasi secara langsung berpengaruh positif dan signifikan terhadap hygiene dan motivator dan variabel hygiene secara langsung berpengaruh positif dan signifikan terhadap komitmen, sedangkan variabel motivator tidak berpengaruh terhadap komitmen. Secara tidak langsung adaptabilitas budaya organisasi berpengaruh positif dan signifikan terhadap komitmen melalui motivasi dengan faktor hygiene. Hal ini dapat menggambarkan bahwa hal yang dapat dilakukan dalam meningkatkan komitmen karyawan di PT Krakatau Steel Tbk harus memerhatikan peran adaptabilitas budaya organisasi dan unsur-unsur yang dapat memotivasi karyawan. 
Penelitian lain yang mendukung dilakukan oleh Taurisa et al. (2012), yang menjelaskan komitmen organisasi berpengaruh dominan terhadap kinerja. Hal ini juga didukung oleh penelitian Hastuti (2013), yang menyatakan komitmen organisasi dan gaya kepemimpinan berpengaruh nyata dan positif terhadap kinerja. Faktor yang memengaruhi kinerja sangat berkaitan dengan tipe organisasi apakah berorientasi pada laba atau nirlaba, apakah BUMN atau non BUMN. Kinerja karyawan juga sangat berhubungan dengan faktor kompetensi organisasi, skala atau ukuran usaha organisasi, karakteristik perusahaan sebagai organisasi pembelajaran, karakteristik karyawan, jenis pekerjaan, budaya organisasi dan gaya kepemimpinan dalam organisasi

Hasil dari analisis Smart PLS dengan mengevaluasi inner yang bertujuan untuk menguji hipotesis dalam penelitian ini. Dimana untuk hipotesis 1 dalam penelitian ini dapat diterima. Artinya, bahwa adaptabilitas budaya organisasi yang diterapkan berpengaruh positif dan signifikan terhadap komitmen karyawan. Hal ini sejalan dengan penelitian yang dilakukan Sunarsih et al. (2010), Mahmudah (2011), dan Hascaryo (2004) yang mengemukakan bahwa adaptabilitas budaya organisasi berpengaruh positif secara langsung terhadap komitmen. Sehingga semakin adaptif budaya organisasi maka semakin tinggi komitmen organisasi.

Pada hipotesis 2 menunjukkan bahwa hygiene secara langsung memiliki pengaruh positif dan signifikan terhadap komitmen. Hasil ini membuktikan bahwa motivasi yang diberikan secara langsung mempunyai pengaruh yang besar dan signifikan terhadap komitmen karyawan pada PT Krakatau Steel Tbk. Pengujian Hipotesis 3 (H3) dalam penelitian ini di terima. Di mana hasilnya menunjukkan adaptabilitas budaya organisasi berpengaruh positif dan signifikan terhadap motivasi dan secara tidak langsung berpengaruh positif dan signifikan terhadap komitmen. Hal ini membuktikan bahwa adaptabilitas budaya organisasi yang diterapkan akan berpengaruh dalam memberikan motivasi kepada karyawan dan berpengaruh secara tidak langsung terhadap komitmen karyawan ke depannya. Hal tersebut sejalan dengan penelitian Kabalmay et al. (2013) yang menyatakan bahwa budaya organisasi berpengaruh secara positif dan signifikan terhadap motivasi. Hal ini di dukung oleh hasil penelitian Hasibuan (2009) yang menyatakan bahwa budaya organisasi secara tidak langsung berpengaruh terhadap komitmen organisasi. Hasil metode bootsrapping model pengaruh langsung (direct effect) dan tidak langsung (indirect effect) dapat dilihat pada Gambar 3.

\section{Pengaruh Adaptabilitas Budaya Organisasi Terhadap Komitmen Organisasi PT Krakatau Steel Tbk}

Adaptabilitas budaya organisasi secara langsung berpengaruh positif dan signifikan terhadap komitmen. Hal ini dapat dilihat dari nilai $\mathrm{T}$ statistik $(3,321)>\mathrm{T}$ tabel $(1,96)$ pada selang kepercayaan $95 \%$. Dan dapat dilihat dari nilai P-values $(0,001)<\alpha(0,05)$. Berdasarkan hasil tersebut dapat dikatakan bahwa adaptabilitas budaya organisasi yang diterapkan di PT Krakatau Steel Tbk mampu memberikan dampak yang besar dan signifikan dalam meningkatkan komitmen karyawan. Semakin adaptif budaya organisasi berpengaruh terhadap komitmen karyawan di organisasi tersebut. Berdasarkan hasil yang didapat bahwa Hipotesis 1 (H1) diterima karena berpengaruh dan signifikan. Hasil ini sejalan dengan penelitian yang telah dilakukan oleh (Brahmasari, 2008), hasil penelitiannya menunjukkan bahwa terdapat hubungan yang positif dan signifikan antara variabel budaya organisasi terhadap variabel komitmen organisasi. Hal ini juga di ukung dengan hasil penelitian yang dilakukan oleh Sunarsih et al. (2010) bahwa adaptabilitas budaya organisasi dan kepuasan kerja berpengaruh positif dan signifikan terhadap komitmen organisasi.

\section{Pengaruh Motivasi Terhadap Komitmen Organisasi PT Krakatau Steel Tbk}

Hasil uji hipotesis untuk motivasi terhadap komitmen dibagi menjadi dua, yaitu hygiene terhadap komitmen yang menghasilkan analisis bootsrap pada koefisien path menghasilkan nilai $\mathrm{T}$ statistik $(2,034)>\mathrm{T}$ tabel $(1,96)$ pada selang kepercayaan 95\%. Dan dapat dilihat dari nilai P-values $(0,043)<\alpha(0,05)$. Hal ini menunjukkan bahwa hygiene secara langsung memiliki pengaruh positif dan signifikan terhadap komitmen. Hasil ini membuktikan bahwa motivasi yang diberikan secara langsung mempunyai pengaruh yang besar dan signifikan terhadap komitmen karyawan pada PT Krakatau Steel Tbk. Artinya, semakin baik motivasi yang diberikan terhadap karyawan akan berdampak terhadap komitmen karyawan yang akan semakin baik juga. Sebaliknya, semakin buruk motivasi yang diberikan kepada karyawan maka akan berdampak semakin menurun pula komitmen karyawan tersebut. Penelitian yang dilakukan oleh Harlie (2012) sesuai 
dengan hasil penelitian ini, yaitu menyatakan pengaruh motivasi lebih kecil dibanding disiplin terhadap kinerja, di mana disiplin kerja merupakan bagian dari komitmen organisasi. Besarnya pengaruh gaya kepemimpinan terhadap motivasi kerja 0,50 satuan, besarnya pengaruh motivasi kerja terhadap gaya kepemimpinan 0,24 , gaya kepemimpinan lebih berperan untuk memengaruhi motivasi kerja dibanding motivasi kerja memengaruhi gaya kepemimpinan.

Motivator terhadap komitmen yang menghasilkan analisis bootsrap pada koefisien path menghasilkan nilai $\mathrm{T}$ statistik $(1,579)<\mathrm{T}$ tabel $(1,96)$ pada selang kepercayaan 95\%. Dan dapat dilihat dari nilai P-values $(0,115)>\alpha(0,05)$. Hal ini menunjukkan bahwa motivator tidak memiliki pengaruh terhadap komitmen. Hal ini membuktikan semakin baik motivasi yang diberikan akan diikuti oleh komitmen yang semakin kuat juga. Hal ini di dukung oleh (Panjisadewa, 2015) motivasi mempunyai pengaruh positif dan signifikan secara langsung terhadap komitmen. Hal ini juga sejalan dengan (Shahbazi dan Davoudi, 2014) dalam penelitiannya juga menyimpulkan bahwa motivasi berpengaruh positif dan signifikan terhadap komitmen.

Berbeda dengan hasil (Fabio, 2016) dalam jurnalnya mengatakan bahwa motivasi kerja mempunyai pengaruh paling besar adalah indikator bangga menyelesaikan pekerjaan. Komitmen organisasi mempunyai pengaruh paling besar adalah indikator membanggakan organisasi kepada orang lain. Kinerja mempunyai pengaruh paling besar adalah indikator kemampuan kerja sama dengan orang lain. Gaya kepemimpinan mempunyai pengaruh lebih besar terhadap komitmen organisasi dibanding terhadap kinerja. Motivasi kerja juga mempunyai pengaruh lebih besar terhadap komitmen organisasi dibanding terhadap kinerja. Komitmen organisasi mempunyai pengaruh paling besar terhadap kinerja dibanding dengan gaya kepemimpinan dan motivasi kerja. Gaya kepemimpinan mempunyai pengaruh lebih besar terhadap motivasi kerja dibanding motivasi kerja terhadap gaya kepemimpinan.

\section{Implikasi Manajerial}

Hasil penelitian terdapat masalah adaptabilitas budaya organisasi yang muncul, yaitu organisasi mengharapkan karyawan untuk meningkatkan prosedur unit kerja dan praktik-praktik yang berjalan, organisasi secara khusus mendorong karyawan membawa perbaikan di tempat kerja dan pimpinan mengakomodir ide-ide dan saran dari para karyawan. Dengan memberikan semangat serta dorongan kepada karyawan maka karyawan tersebut akan merasa dibutuhkan dan hal ini dapat memberikan dorongan emosional dan termotivasi dalam diri karyawan tersebut untuk menyelesaikan pekerjaan selanjutnya yang diberikan dengan baik dan diikuti dengan meningkatkan komitmen karyawan. Meningkatkan motivasi karyawan menjadi salah satu faktor penting yang perlu diperhatikan bagi PT Krakatau Steel Tbk. Hasil dari penelitian ini memberikan indikasi bahwa dalam meningkatkan motivasi karyawan PT Krakatau Steel Tbk terdapat beberapa hal yang harus di evaluasi dan diperbaiki oleh PT Krakatau Steel Tbk seperti, para karyawan saling memberikan bantuan dan kerja sama tim yang baik, karyawan menunjukkan rasa tanggung jawab yang besar setiap melaksanakan tugas dan pekerjaan dan hubungan para karywan di luar pekerjaan sudah erat. Hal ini menjadi fokus utama yang harus diperbaiki dan dievaluasi oleh PT Krakatau Steel Tbk dalam meningkatkan motivasi karyawan karena meningkatnya motivasi karyawan akan diikuti dengan komitmen yang kuat dari karyawan PT Krakatau Steel Tbk.

Hasil penelitian mengindikasikan bahwa adanya hubungan yang signifikan antara motivasi dengan komitmen. Hal ini menunjukkan bahwa salah satu faktor yang menentukan komitmen adalah motivasi. PT Krakatau Steel Tbk harus memiliki karyawan yang mempunyai komitmen yang tinggi. Oleh karena itu, komitmen menjadi salah satu faktor penting dalam mencapai tujuan organisasi. Komitmen yang dimiliki karyawan PT Krakatau Steel Tbk lebih mendominasi pada affective commitment. Komitmen yang tinggi dapat meningkatkan tanggung jawab yang tinggi pada karyawan untuk tetap terikat pada organisasi. Adanya keterikatan emosional yang kuat antara karyawan dan organisasi karena karyawan merasa menjadi bagian dari keluarga besar PT Krakatau Steel Tbk sehingga PT Krakatau Steel Tbk layak mendapatkan loyalitasnya. Komitmen karyawan pada organisasi yang tinggi maka karyawan menunjukkan perilaku ekstra bagi PT Krakatau Steel Tbk dengan tingkat loyalitas yang tinggi. Hal yang harus diperbaiki oleh PT Krakatau Steel Tbk untuk meningkatkan normative commitment dan continuance commitment seperti, memberikan pelatihan kepada karyawan untuk lebih maju sehingga karyawan merasa berhutang budi terhadap organisasi yang telah memberikan ilmu yang berharga dan hal ini akan diikuti dengan komitmen karyawan yang meningkat. Selain itu, dengan memberikan peluang 
untuk maju kepada karyawan akan membuat karyawan termotivasi untuk bekerja lebih baik lagi dan karyawan akan merasa lebih baik berkarir di dalam organisasi dibandingkan dengan di luar PT Krakatau Steel Tbk.

\section{KESIMPULAN DAN SARAN}

\section{Kesimpulan}

Hasil penelitian secara umum dapat disimpulkan bahwa adaptabilitas budaya organisasi berpengaruh positif dan signifikan terhadap komitmen. Hal ini mengindikasikan bahwa adaptabilitas budaya organisasi memiliki hubungan yang kuat dan dapat memengaruhi komitmen. Hasil ini menunjukkan bahwa semakin adaptif budaya organisasi maka semakin tinggi komitmen karyawan. Adaptabilitas budaya organisasi berpengaruh positif dan signifikan terhadap motivasi. Untuk itu variabel ini perlu menjadi perhatian bagi PT Krakatau Steel Tbk. Penerapan adaptabilitas budaya organisasi secara baik diperlukan untuk membentuk dan memberikan motivasi kepada karyawan. Semakin baik penerapan adaptabilitas budaya organisasi dalam memberikan motivasi akan diikuti oleh motivasi karyawan yang semakin meningkat.

Hasil penelitian juga menunjukkan bahwa hygiene factors berpengaruh positif dan signifikan terhadap komitmen karyawan PT Krakatau Steel Tbk. Nilai tertinggi terdapat pada indikator gaji ini merupakan faktor yang dapat memengaruhi faktor-faktor lain, seperti supervisi, hubungan kerja antara atasan dan bawahan, hubungan atasan sesama rekan kerja, kebijakan organisasi, dan kondisi kerja. Motivator factors menunjukkan bahwa tidak berpengaruh terhadap komitmen karyawan PT Krakatau Steel Tbk. Sehingga dalam praktiknya PT Krakatau Steel Tbk harus memperhatikan motivator factors agar terjaga dengan baik untuk meningkatkan komitmen karyawan PT Krakatau Steel Tbk. Variabel motivasi perlu menjadi perhatian bagi PT Krakatau Steel Tbk. Semakin baik motivasi yang diberikan kepada karyawan akan diikuti dengan komitmen yang kuat pula.

\section{Saran}

Berdasarkan kesimpulan yang telah diperoleh, secara umum penerapan adaptabilitas budaya organisasi sudah dapatdikatakan cukupbaiksehingga dapatmemengaruhi karyawan dalam menyelesaikan pekerjaannya.
Keterbukaan kesempatan dalam memberikan ide, saran dan pembaharuan merupakan salah satu kunci untuk meningkatkan adaptabilitas budaya organisasi. Dalam meningkatkan adaptabilitas budaya organisasi dan motivasi memerlukan komitmen penuh dari pimpinan untuk mengeluarkan program-program yang dapat meningkatkan komitmen karyawan.

Faktor-faktor motivasi yang sudah terbangun saat ini harus dapat menjadi perhatian organisasi untuk memelihara dan menjaga faktor-faktor tersebut agar komitmen karyawan terjaga dengan baik. Dengan melakukan peningkatan motivasi karyawan yang lebih baik maka organisasi akan memperoleh komitmen yang lebih kuat dari karyawan sehingga akan lebih mampu bertahan terhadap tantangan perubahan lingkungan. Diharapkan ada penelitian lebih lanjut mengenai pengaruh adaptabilitas budaya organisasi dan motivasi terhadap komitmen yang dilakukan dengan menggunakan indikator-indikator dari teori lain. Organisasi yang di pilih menjadi objek penelitian dapat dipertimbangkan agar penelitian dapat dilakukan di organisasi yang berbeda seperti organisasi pendidikan, perusahaan perbankan dan perusahaan jasa.

\section{DAFTAR PUSTAKA}

Abrivianto O. 2014. Pengaruh motivasi kerja dan komitmen organisasional terhadap kinerja karyawan. Jurnal Administrasi Binis 7(2) : 1-9.

Brahmasari IA .2008. Pengaruh budaya organisasi dan motivasi kerja terhadap komitmen karyawan kinerja perusahaan. Jurnal Aplikasi Manajemen 7(1): 96-108.

Denison DR, Aneil KM. 1990. Toward of organizational culture and effectiveness. Organization Science 6(2): 204-223.

Ghozali I. 2008. Structural Equation Modelling Alternatif dengan Partial Least Square, Edisi 2. Semarang: Badan Penerbit Universitas Dipenogoro.

Harlie M. 2012. Pengaruh disiplin kerja, motivasi, dan pengembangan karier terhadap kinerja pegawai negeri sipil pada pemerintah Kabupaten Tabalong di Tanjung Kalimantan Selatan. Jurnal Aplikasi Manajemen 10(4):860-867.

Hascaryo A. 2004. Analisis pengaruh motivasi karyawan dan budaya organisasi terhadap komitmen organisasional dan dampaknya pada kinerja karyawan (studi kasus di PT. Apac Inti 
Corpora, Tbk) [tesis]. Program Studi Magister Manajemen Universitas Diponegoro Semarang.

Hasibuan. 2009. Pengaruh budaya organisasi dan kepuasan insentif terhadap komitmen organisasi. Jurnal Administrasi Bisnis (JAB) 25(2).

Hastuti RT. 2013. Komitmen organisasi dan gaya kepemimpinan dalam penerapan penganggaran berbasis kinerja badan layanan umum. Jurnal Terpadu Ilmu Kesehatan 3:175-179.

Kabalmay J, Hubeis AV, Dirdjosuparto S, Susanty I. 2013. Pengaruh budaya organisasi dan motivasi terhadap komitmen pegawai politeknik perikanan negeri tual. Jurnal Ilmu Manajemen (JUIMA) 5(1): 34-42.

Kotter JP, Heskett JL. 1998. Corporate Culture and Performance. Penerjemah Benyamin Molan. Jakarta: Prehallindo.

Mahmudah. 2011. Influence of motivation and culture on organizational commitment and performance of employee of medical service. Academic Research International 1(3):228-235.

McNeese -S, Donna. 1996. Increasing employee productivity, job satisfaction, and organizational commitment. Hospital \& Health Services Administration 41(2):160-175

Rashid MAA, Sambasivan M, Johari J. 2003. The influence of corporate culture and organizational commitment on performance. Journal of Management Development 22(8):708-728.

Robbins, Stephen P. 1996. Organizational Behavior Concept, Controversiest, Application. Eaglewoods Cliffs, Prentice Hall Inc.

Sadewa AP. 2015. Pengaruh kepemimipinan dan motivasi terhadap komitmen Pegawai Dinas
TPHP 2 KKP Kabupaten Belitung. Jurnal Ilmu Manajemen 23(5).

Shahbazi Q, Davoudi MH. 2014. The influence of employee understanding of adaptability on employee understanding of learning organizational dimensions. Kuwait Chapter of Arabian Journal of Business and Management Review 3(11a): 115-120.

Sumarno J. 2005. Pengaruh komitmen organisasi dan gaya kepemimpinan terhadap hubungan antara partisipasi anggaran dan kinerja manajerial. Jurnal Bisnis Strategi 14(2): 197-210.

Sunarsih N, Hartoyo S, Dirdjosuparto S. 2010. Pengaruh budaya organisasi dan kepuasan kerja terhadap komitmen organisasi staff administrasi universitas terbuka. Forum Pasca Sarjana 15(3):125-133.

Taurisa M, Chaterina, Intan R. 2012. Analisis pengaruh budaya organisasi dan kepuasan kerja terhadap komitmen organisasional dalam meningkatkan kinerja karyawan (Studi pada PT Sido Muncul Kaligawe Semarang). Jurnal Bisnis dan Ekonomi 19(2):170-187.

Trang DS. 2013. Gaya kepemimpinan dan budaya organisasi pengaruhnya terhadap kinerja karyawan. Jurnal Riset Ekonomi, Manajemen, Bisnis dan Akuntansi 1(3):208.

Yilmaz C, Ergun E. 2008. Organizational culture and firm effectiveness: An examination of relative effects of culture traits and the balanced culture Contemporary Management Research 323 hypothesis in an emerging economy. Journal of World Business 43(3):290-306. 